\title{
Шановні колеги!
}

Завершується 2021 рік, протягом якого на шпальтах журналу ми ділилися з вами новими технологіями з діагностики, лікування та профрілактики основних стоматологічних хвороб, публікували методичні рекомендації, наукові статті. Протягом року ми висвітлювали головні новини стоматологічної спільноти, святкували 65-ту річницю професійного об'єднання лікарів-стоматологів України, публікували матеріали III Українського конгресу 3 міжнародною участю «Інтегрована медицина та стоматологія» та 6-го Національного українського стоматологічного конгресу 3 міжнародною участю «Інноваційні технології в стоматології», у яких вітчизняні науковці і практикуючі лікарі навели свої наукові здобутки, напрацювання в галузі стоматології.

Одним із актуальних напрямків фрахового журналу було відтворення історії стоматології України, адже «хто не пам'ятає свого минулого, не має майбутнього», і ми крок за кроком відтворювали події стоматологічної галузі початку XX століття.

На шпальтах четвертого номера журналу «Oral and General Health» подано методичні розробки з питань діагностики злоякісних новоутворень ротової порожнини (частина 1). Згідно з прийнятими рішеннями координаційної ради ГО «Асоціація стоматологів України» (протокол засідання № 1 від 01.07.2021) та відповідно до резолюції 6-го Національного українського стоматологічного конгресу «ннноваційні технології в стоматології» групою науковців підготовлено методичні рекомендації з питань ранньої діагностики злоякісних новоутворень губ та ротової порожнини.

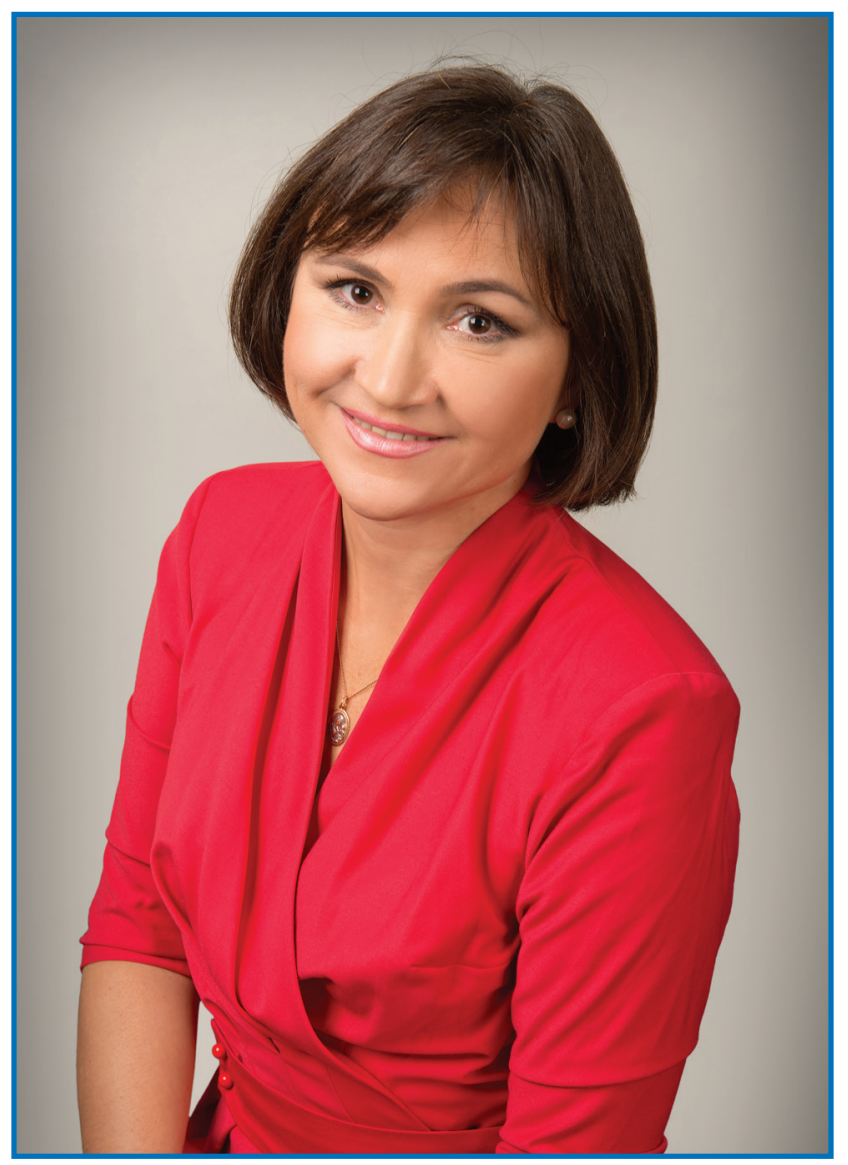

Редакційна рада журналу запрошує лікарів-стоматологів, лікарів загальної практики, науковців до створення якісного контенту нашого видання!

Маємо честь запросити вас до участі в IV Українському конгресі 3 міжнародною участю «Інтегрована медицина та стоматологія», який відбудеться 7-8 квітня 2022 року в Києві і буде присвячений Всесвітньому дню здоров'я порожнини рота.

Запрошуємо до співпраці!

3 повагою, головний редактор журналу професор Ірина Мазур 